\title{
Polysaccharide-rich fraction of Agaricus brasiliensis enhances the candidacidal activity of murine macrophages
}

\author{
Priscila Raquel Martins/", Maria Carolina Gameiro/2, Lindsey Castoldi/", Graziela Gorete Romagnoli/", \\ Fabiane Catanho Lopes/ ${ }^{1}$, Andréa Vanessa Ferreira da Silva Pinto/ ${ }^{1}$, Wagner Loyola ${ }^{3}$, Ramon Kaneno/ ${ }^{1 /+}$ \\ Departamento de Microbiologia e Imunologia, Instituto de Biociências, Universidade Estadual Paulista, Distrito Rubião Jr. s/n, Caixa \\ Postal 510, 18618-000 Botucatu, SP, Brasil 'Departamento de Patologia, Faculdade de Medicina-UNESP ${ }^{2}$ Departamento de Doenças \\ Tropicais e Diagnóstico por Imagem, Faculdade de Medicina-UNESP ${ }^{3}$ Universidade Bandeirantes, Bandeirantes, PR, Brasil
}

A polysaccharide-rich fraction (ATF) of medicinal mushroom Agaricus brasiliensis was evaluated on the candidacidal activity, $\mathrm{H}_{2} \mathrm{O}_{2}$ and nitric oxide (NO) production, and expression of mannose receptors by murine peritoneal macrophages. Mice received three intraperitoneal (i.p.) injections of ATF and after $48 \mathrm{~h}$ their peritoneal resident macrophages were assayed against Candida albicans yeast forms. The treatment increased fungicidal activity and it was associated with higher levels of $\mathrm{H}_{2} \mathrm{O}_{2}$, whereas NO production was not affected. We also found that the treatment enhances mannose receptor expression by peritoneal macrophages, which are involved in the attachment and phagocytosis of non-opsonized microorganisms. Treatment of animals with ATF was able to enhance the clearance of C. albicans during the first $6 \mathrm{~h}$ after the experimental i.p. infection. Our results suggest that this extract can increase host resistance against some infectious agents through the stimulation of microbicidal activity of macrophages.

Key words: Candida albicans - microbicidal activity - mushroom

Candida albicans is a very common dimorphic fungus that can cause opportunistic infection and, although most people are resistant to this agent, candidiasis is the most frequent fungal infection among immune depressed individuals such as diabetes (Donders 2002), cancer (Ridola et al. 2004) and HIV patients (Klein et al. 1984). Resistance to C. albicans depends on a coordinated action of innate and adaptive immune defenses, a process to which phagocytosis by granulocytes and macrophages is crucial. The destruction of microorganisms by phagocytic cells involves both the recognition/ attachment to cell surfaces and phagocytosis/endocytosis, followed by the killing processes. The binding of pathogens to macrophage surfaces initiates the secretion of a wide array of inflammatory mediators including arachidonic acid metabolites, neutral proteases and reactive oxygen intermediates $\left(\mathrm{H}_{2} \mathrm{O}_{2}, \mathrm{O}_{2}^{-}, \mathrm{OH}^{-}\right)$ and nitric oxide (NO), all of which are highly toxic to most of microorganisms (Goldsby et al. 2000). Administration of $\beta$-glucan obtained from different sources has been demonstrated to stimulate the microbicidal activity of macrophages (Suzuki et al. 1990, Sakurai et al. 1991). These cells show a variety of surface molecules that enhance the phagocytic function, such as receptors for complement (CR1 and CR3), IgG Fc portion, and the pattern-recognition receptors (PRR), like the mannose-receptors (MR) and toll-like recep-

Financial support: FAPESP (98/07726-5R)

+ Corresponding author: rskaneno@yahoo.com.br

Received 3 October 2007

Accepted 10 April 2008 tors, which are involved in the recognition and phagocytosis of non-opsonized microorganisms. MR was first identified on Küpffer cells of rats as a specific uptake system for mannosylated/N-acetylglucosamine-terminal and fucosylated glycoproteins (Schlesinger et al. 1978). Further studies have demonstrated their presence on alveolar (Stahl et al. 1978) and peritoneal macrophages (Stahl et al. 1982) as well as on human mononuclear phagocytes (Shepherd et al. 1982). Many studies have suggested that the main role of MR is the endocytic clearance of host-derived glycoproteins (Smedsrod et al. 1988) and it is also widely accepted that MR can mediate the phagocytosis of non-opsonized microorganisms through interaction with polysaccharide structures of cell walls, such as yeast mannan, bacterial capsules, lipopolysaccharides, and lipoarabinomannan (Ofek et al. 1995).

Agaricus blazei Murrill - whose Brazilian variety was recently suggested for classification as a new species to be named Agaricus brasiliensis sp. nov. (Wasser et al. 2002) - is a medicinal mushroom whose characteristics include a wide range of medicinal properties including antitumoral (Mizuno et al. 1990a, b) and immunostimulatory activities (Ito et al. 1997, Fujimiya et al. 1998). The main bioactive substances of this mushroom are polysaccharides obtained from the fruiting bodies (Mizuno et al. 1990a, b, Ebina \& Fujimiya 1998, Fujimiya et al. 1998), and its immunomodulatory activity is attributed mainly to $\beta$-glucans (Mizuno et al. 1990a, b, Ito et al. 1997), which are also found in other species of edible mushrooms such as Lentinus edodes and Ganoderma lucidum (Borchers et al. 1999).

There are few reports on the metabolic pathway of $(1 \rightarrow 3)-\beta$-D-glucans in the host. Vertebrate cells do not possess $(1 \rightarrow 3)-\beta$-D-glucanases and cannot rapidly metabolize these carbohydrates, but in fact metabolize them 
slowly through oxidation (Nono et al. 1991). In vivo the clearance of $(1 \rightarrow 3)-\beta$-D-glucans depends on their molecular weight so that low-molecular-weight glucans are excreted through glomerular filtration, whereas large molecules are retained primarily in the liver. These larger $\beta$-glucans are metabolized by Küpffer cells and this process may take several weeks (Suda et al. 1996).

A polysaccharide-rich fraction obtained by acid treatment of the ammonium oxalate-soluble extract of A. blazei (ATF) was shown to be able to cause tumor infiltration by NK cells; and it inhibits in vitro tumor cell growth by inducing apoptosis (Fujimiya et al. 1998, 1999). Sorimachi et al. (2001) have observed that extracts from A. blazei are able to activate macrophage functions. Our previous results have shown that the oxalate-soluble polysaccharide fraction was able to inhibit the growth of Ehrlich tumor and partially inhibit the production of IL-10 by spleen cells of tumor-bearing mice (unpublished observations). Although there are only two works reporting the effects of A. blazei on human diseases (Ahn et al. 2004, Grinde et al. 2006), people of many countries habitually consume this mushroom prepared as tea or pills (whole dried and powdered fruiting bodies).

Since mushroom polysaccharides are able to activate lymphocytes and macrophages (Ebina \& Fujimiya 1998, Fujimiya et al. 1998, Borchers et al. 1999, Sorimachi et al. 2001) in the present work we aimed to explore, for the first time, the usefulness of ATF against opportunistic fungi. Thus we evaluated the effect of ATF inoculation on candidacidal activity, spontaneous $\mathrm{H}_{2} \mathrm{O}_{2}$ and $\mathrm{NO}$ release, and the expression of MR on peritoneal resident macrophages.

\section{MATERIALS AND METHODS}

Animals and ATF treatment - Specific pathogen-free male $\mathrm{BALB} / \mathrm{c}$ mice aged 45 days were handled according to the recommendations of the Brazilian College of Animal Experimentation. All procedures were approved by the Animal Research Ethics Committee of the Institute of Biosciences (CEEA n ${ }^{\circ}$ 039/04). For assaying the ex vivo fungicidal activity, phagocytosis, $\mathrm{H}_{2} \mathrm{O}_{2}$ and $\mathrm{NO}$ release, and MR expression, animals $(n=6)$ were treated intraperitoneally (i.p.), with $500 \mu \mathrm{g}$ of ATF or phosphatebuffered salt (PBS) (0.01M PBS solution, $\mathrm{pH}$ 7.2) for three consecutive days, following standardization in a tumorbearing mice model (unpublished observations).

Forty-eight hours after the last dose, peritoneal cells were collected by washing the cavity with cold PBS. Afterwards cell suspension was plated on 24- or 96-well culture plates, as detailed in a later item.

ATF - The ATF of A. brasiliensis was obtained according to Fujimyia et al. (1998). Before use, ATF was rehydrated with PBS and the sample was autoclaved in order to obtain a sterile solution (previous experiments have shown that autoclaved samples were more efficient against tumor growth than filtered ones). The use of $A$. brasiliensis in this study is in accordance with the Brazilian rules for Biodiversity (IBAMA - Instituto Brasileiro do Meio Ambiente e Recursos Naturais Renováveis).
The presence of oxalate was checked by heating ATF samples with $500 \mu \mathrm{l}$ of $0.1 \mathrm{~N}$ potassium permanganate for $1 \mathrm{~min}$ at $100^{\circ} \mathrm{C}$. The final solution of ATF was compared with a standard curve $(4.0 ; 2.0 ; 0.5 ; 0.25$ and $0.125 \%)$ prepared with $1 \mathrm{~N} \mathrm{HCl}$ (Borchers et al. 1999), showing that the residual concentration of oxalate was lower than $0.125 \%$. Endotoxin was analyzed by a Lymulus amebocyte lysate test (E-toxate kit - Sigma ET0200), and this extract presented less than $0.06 \mathrm{EU} / \mathrm{ml}$.

C. albicans suspension - Yeast cells of C. albicans, sample $\mathrm{H}-428 / 03$, originally isolated from a patient of Hospital das Clínicas de Botucatu (SP, Brazil) and maintained at $-70^{\circ} \mathrm{C}$, were defrosted and grown in SabouraudDextrose-Agar medium (Oxoid, Ltd.), at $35^{\circ} \mathrm{C}$ for $24 \mathrm{~h}$. Cells were collected and washed with sterile pyrogen-free salt-solution and adjusted to $2 \times 10^{6}$ yeasts $\mathrm{ml}^{-1}$. The viability of yeast cells was evaluated by phase-microscopy ( $99 \%$ of viable cells).

Macrophage monolayer preparation and challenge with C. albicans - Peritoneal resident macrophages were collected by washing the cavity with cold PBS. Cell suspensions were washed twice with cold complete tissue culture medium $(\mathrm{CTCM}=\mathrm{RPMI}$ 1,640 liquid culture medium supplemented with $10 \%$ fetal calf serum, $20 \mathrm{mM}$ HEPES, $200 \mathrm{mM}$ L-glutamine and $40 \mu \mathrm{ml}^{-1}$ gentamicine) and macrophages were counted with neutral red solution $(0.02 \%)$ set at $4 \times 10^{5}$ cells ml-1 . Two hundred microliters of cell suspensions was dispensed into 24-well cell culture plates (Nunc, Life Tech. Inc., Maryland, USA) following incubation for $2 \mathrm{~h}$ at $37^{\circ} \mathrm{C}$ under $5 \% \mathrm{CO}_{2}$. Wells were rinsed twice with $\mathrm{CTCM}$ at $37^{\circ} \mathrm{C}$ and non-adherent cells were removed by aspiration of the supernatant.

Adherent cells were then challenged with $2 \times 10^{6}$ yeast cells of C. albicans (ratio yeast:macrophage $=25: 1$ ) for $30 \mathrm{~min}$ at $37^{\circ} \mathrm{C}$ under $5 \% \mathrm{CO}_{2}$. C. albicans yeast cells diluted with CTCM at the same concentration $\left(2 \times 10^{6}\right)$ were plated into wells of the culture plate without macrophages (C. albicans control cultures). After this time, the adherent monolayer was detached and lysed by washing each well with sterile non-pyrogenic distilled water (final volume of $2 \mathrm{ml}$ ). Samples of recovered suspensions were diluted 1:300 and $100 \mu \mathrm{l}$ of each suspension was plated on Sabouraud medium for $48 \mathrm{~h}$ at $35^{\circ} \mathrm{C}$, following the counting of colony forming units (CFU). The percentage of C. albicans recovery was determined by the formula: $\% \mathrm{CFU}$ recovery $=$ (mean CFU of experimental culture/ mean CFU of control culture) x 100.

Phagocytosis assay - Peritoneal resident macrophages were collected and $3 \times 10^{5}$ cells/chamber were cultured in 8-chamber slides (Nunc). The cells were incubated at $37^{\circ} \mathrm{C}$, under $5 \% \mathrm{CO}_{2}$ tension and after $2 \mathrm{~h}$ non-adherent cells were removed by washing each chamber with CTCM. Adherent cells were then challenged with $15 \times 10^{5}$ yeast cells of $C$. albicans (yeast:macrophage ratio $=5: 1$ ) for $30 \mathrm{~min}$ at $37^{\circ} \mathrm{C}$ under $5 \% \mathrm{CO}_{2}$. After this period the slides were washed with complete culture medium, dyed with May-Grünwald-Giemsa and analyzed under light microscopy. Results were expressed as phagocytic index 
calculated as the average number of attached plus ingested yeasts per phagocytizing cell multiplied by proportion of phagocytizing cells (Muniz-Junqueira et al. 2005).

Assay for spontaneous release of hydrogen peroxide $\left(\mathrm{H}_{2} \mathrm{O}_{2}\right)$ and $\mathrm{NO}-\mathrm{H}_{2} \mathrm{O}_{2}$ release by peritoneal macrophages was determined using the horseradish peroxidase-dependent phenol red oxidation microassay according to Pick and Mizel (1981). NO release was determined by assaying culture supernatants for nitrite using Griess reagent according to Green (1981).

Analysis of MR expression- Normal mice were inoculated with ATF sterile solution (500 $\mu \mathrm{g} / \mathrm{day})$ for three days, according to previous standardization. Normal control mice were inoculated with $0.5 \mathrm{ml}$ of sterile PBS and positive controls received $500 \mu \mathrm{g}$ of concanavalin A (Con A) $24 \mathrm{~h}$ before the collection of peritoneal cells. Expression of MR by peritoneal adherent cells was evaluated by using FITC-labeled bovine serum albumin (FITCBSA - Sigma), according to Loyola et al. (2002).

Clearance kinetics of $C$. albicans in the peritoneal cavity - Animals were i.p. treated with PBS (control group) or different doses of ATF (100, 500 or $2,000 \mu \mathrm{g} /$ animal) for three consecutive days. Forty-eight hours after the last dose, the animals were i.p. inoculated with $5 \times 10^{6}$ C. albicans; and 1,6 or $24 \mathrm{~h}$ after infection, the peritoneal cavity was washed with $20 \mathrm{ml}$ of PBS. Twenty-five microliters of this suspension was plated on Sabouraud medium and colonies were enumerated after $48 \mathrm{~h}$ of culture at $35^{\circ} \mathrm{C}$.

Statistical analysis - All the experiments, except analysis of MR, were performed at least twice. Data from one representative experiment were analyzed by the unpaired Student's $t$ test when we had only two groups or transformed to square roots and analyzed by StudentNewman-Keuls for multiple comparisons (INSTAT software - Graph Pad, San Diego, CA). Significant difference between groups was concluded for $p<0.05$.

\section{RESULTS}

Ex vivo fungicidal activity - As can be observed in Fig. 1, the i.p. administration of ATF was able to significantly enhance the capacity of peritoneal resident macrophages to kill C. albicans yeast cells in a $30 \mathrm{~min}$ in vitro challenge assay (Control vs. ATF; $p<0.05$ ). The average number of CFUs observed in the control group was $100.17 \pm 13.27$ CFUs, whereas ATF-treated animals showed $80.17 \pm 6.88$ CFUs $(p<0.01)$. Analysis of the phagocytic index of peritoneal cells on C. albicans yeasts (Fig. 2) showed a significant effect of the treatment on phagocytotic activity (Control $=3.42 \pm 0.91$ vs. $\mathrm{ATF}=7.93 \pm 2.00 ; \mathrm{p}=0.0005$ ). Morphological observation of these cells have shown that macrophages of ATFtreated animals showed many more phagocytic vacuoles than cells of normal controls (Fig. 3).

Spontaneous production of $\mathrm{H}_{2} \mathrm{O}_{2}$ and $\mathrm{NO}$ - Production of $\mathrm{H}_{2} \mathrm{O}_{2}$ by peritoneal macrophages is shown in Fig. 4, where it can be observed that ATF-treated mice produced higher levels $\left(2.00 \pm 0.54 \mathrm{nmol} / 2 \times 10^{5}\right.$ cells) of this metabolite than control animals (1.06 \pm $0.16 \mathrm{nmol} / 2 \times 10^{5}$ cells; $\left.\mathrm{p}<0.001\right)$. Our data indicate that ATF treatment was unable to modify spontaneous NO production (Fig. 5).

$M R$ expression - The treatment of normal mice with ATF increased the expression of MR on macrophage surfaces. In Fig. 6 it can be observed that i.p. inoculation of $500 \mu \mathrm{g}$ of ATF (3 consecutive days) induced a more intense reactivity than did the positive control (Con A).

Clearance kinetics of C. albicans in the peritoneal cavity - Since ATF caused a significant increase in the in vitro killing activity of peritoneal resident macrophages (Fig. 1) and produced higher levels of $\mathrm{H}_{2} \mathrm{O}_{2}$ (Fig. 4), we decided to evaluate the in vivo effect of this extract. Thus animals were pretreated with different doses of ATF in order to assess their ability to clear C. albicans inoculated in the peritoneal cavity. As can

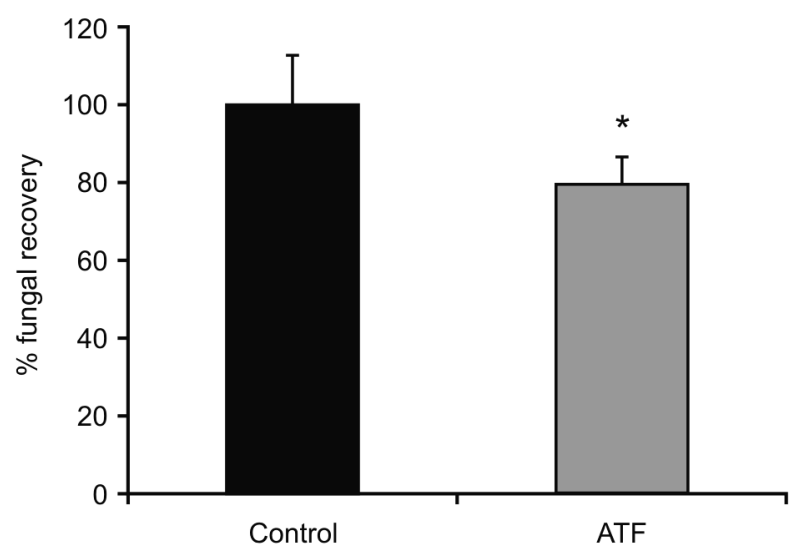

Fig. 1: enhancement of killing activity against C. albicans by i.p. inoculation of ATF in normal BALB/c mice. Results represent the mean \pm SD of six mice in each group of a representative experiment (asterisks indicate $\mathrm{t}=3.276$ with 10 degrees of freedom, $\mathrm{p}=0.0083$; Student's $t$ test).

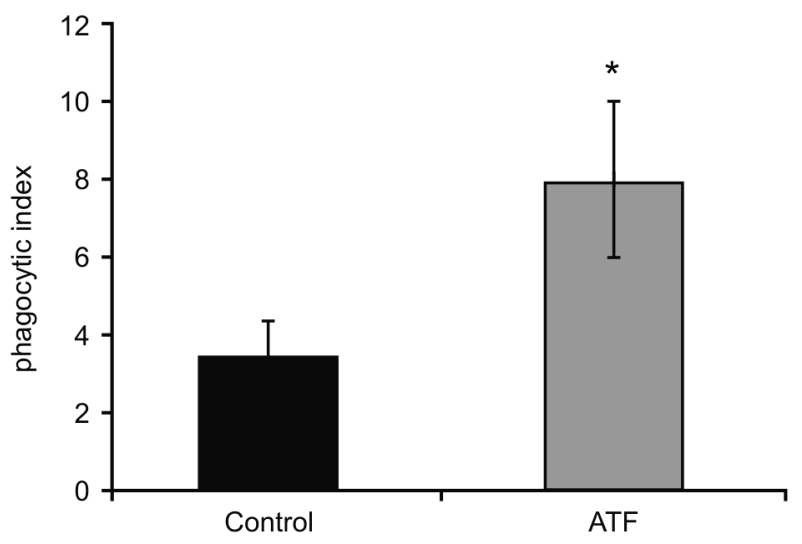

Fig. 2: increased phagocytosis activity by peritoneal macrophages of normal BALB/c mice, after i.p. inoculation of ATF. Animals received $500 \mu \mathrm{g} /$ day during three consecutive days before evaluation. Results represent the mean phagocytic index $\pm \mathrm{SD}$ of six mice in each group of a representative experiment (asterisks indicate $\mathrm{t}=5.018$ with 10 degrees of freedom, $\mathrm{p}=0.0005$; Student's $t$ test). 


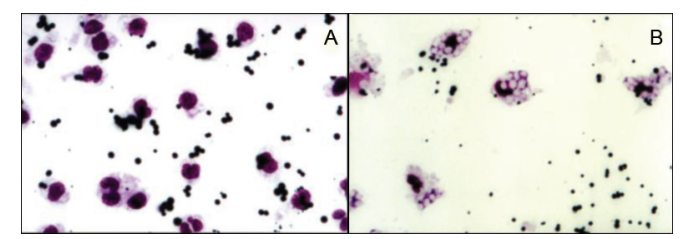

Fig. 3: effect of i.p. inoculation of ATF in normal BALB/c mice on the phagocytic activity of peritoneal macrophages against $C$. albicans (yest:macrophage ratio $=5: 1$ ). A: control group; B: macrophages of ATF group show increased number of digestive vacuoles after in vivo treatment. May-Grünwald-Giemsa, 400X.

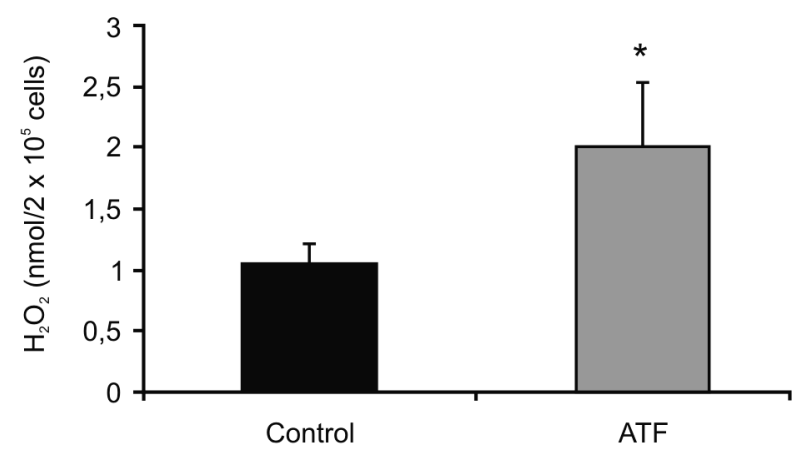

Fig. 4: increased spontaneous production of $\mathrm{H}_{2} \mathrm{O}_{2}$ by peritoneal macrophages of normal BALB/c mice, after i.p. inoculation of ATF. Animals have received $500 \mu \mathrm{g}$ /day during three consecutive days before evaluation. Results represent the mean $\pm \mathrm{SD}$ of six mice in each group of a representative experiment (asterisks indicate $t=4.025$ with 10 degrees of freedom, $\mathrm{p}=0.0024$; Student's $t$ test).

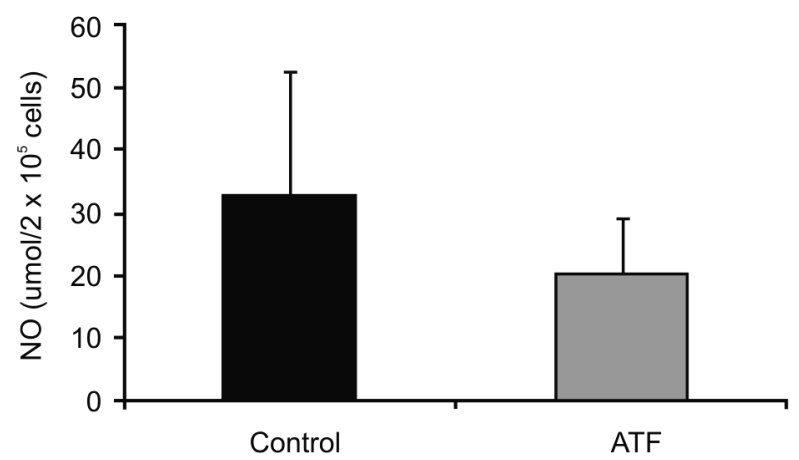

Fig. 5: spontaneous production of NO by peritoneal macrophages of normal BALB/c mice, after i.p. inoculation of ATF. Animals have received $500 \mu \mathrm{g}$ /day during three consecutive days before evaluation. Results represent the mean \pm SD of six mice in each group of a representative experiment $(\mathrm{t}=1.543$ with 12 degrees of freedom, $\mathrm{p}=0.1489 ;$ Student's $t$ test).

be observed in Fig. 7, i.p., administration of ATF for three consecutive days enhanced the killing of $C$. albicans in the first $6 \mathrm{~h}$ after infection. The best results were observed by using $500 \mu \mathrm{g} /$ day (control vs. ATF 500; p < 0.05). The number of CFUs found in the control group $1 \mathrm{~h}$ after infection was $25.13 \pm 3.11$ CFUs, whereas animals treated with $500 \mu \mathrm{g}$ ATF showed $19.35 \pm 5.70$ CFUs. The number of CFUs observed in the control group $6 \mathrm{~h}$ after infection diminished to $8.42 \pm 4.97$ CFUs, whereas animals treated with $500 \mu \mathrm{g}$ ATF presented only $4.02 \pm 2.06$ CFUs.

\section{DISCUSSION}

The antitumoral activity of $A$. brasiliensis (formerly A. blazei) has been documented through several experimental studies and it is mainly attributed to $\beta$-glucan (Mizuno et al. 1990a, b, Fujimiya et al. 1998, Sorimachi et al. 2001); however, there is only one report of its effect against infectious diseases in which the authors analyzed patients with hepatitis C (Grinde et al. 2006). In the present study we analyzed, for the first time, the antifungal effect of a polysaccharide fraction of $A$. brasiliensis ATF and observed that the i.p. inoculation of ATF for just three consecutive days was able to enhance the ability of peritoneal macrophages to kill C. albicans yeast both ex vivo (Fig. 1) and in the peritoneal cavity (Fig. 7).

Fujimyia et al. (1998) demonstrated that ATF inhibits the development of Meth A fibrosarcoma by inoculating $500 \mu \mathrm{g} / \mathrm{day}$. This same dose was chosen in our study because it was also effective against the development of Ehrlich tumor cells and during the standardization phase; it gave us the best results on the in vitro C. albicans phagocytosis assay. Extraction of ATF was previously standardized in our laboratory (unpublished observations), according to Fujimyia et al. (1998); and analysis by nuclear magnetic resonance demonstrated that our extract is similar to that presented earlier by the first group to show the antitumoral property of $A$. blazei (Kawagishi et al. 1989, 1990). The protein $(13.4 \%)$ and carbohydrate $(86.6 \%)$ concentrations indicate that this extract is rich in carbohydrates as also demonstrated by Ebina et al. (1998). Fujimyia et al. (1998) demonstrated that the antitumoral and immunostimulatory effects of ATF were due to $(1 \rightarrow 4)-\alpha$-D-glucan with $(1 \rightarrow 6)-\beta$-Dglucan branches, in a 4:1 ratio. Analysis by HMQC showed that the main compound of our extract has a $(1 \rightarrow 6)-\beta$-glucan structure (data not shown).

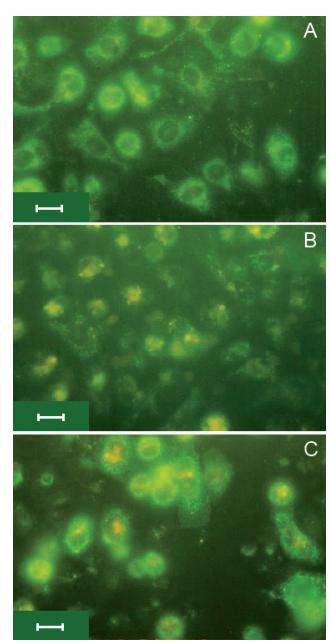

Fig. 6: enhanced expression of mannose receptors (MR) by peritoneal macrophages of normal BALB/c mice, after i.p. inoculation of ATF. Samples were analyzed through fluorescent microscopy after labeling with FITC-labeled $\alpha$-D-mannosylated BSA for 60 min. A: control group, inoculated with PBS; B: positive control inoculated with $500 \mu \mathrm{g}$ of Con-A $24 \mathrm{~h}$ before evaluation; C: ATF group treated with $500 \mathrm{mg} /$ day during three consecutive days before evaluation. 400X. 
Although patients habitually consume the whole dried mushroom or tea orally, we decided to administer ATF through the i.p. route because: a) we were interested in its effect on macrophages; b) we would like to avoid loss of activity due to digestive enzymes; c) vertebrate hosts do not have $\beta$-glucanases to metabolize ATF, an absence which could drastically reduce its biological effects, and d) this route was previously used by other authors (Sakurai et al. 1991). Of course the oral route should also be analyzed in further studies to assess the feasibility of using it for human diseases.

Higher ex vivo candidacidal activity of macrophages in ATF-treated mice was associated with higher phagocytic ability, as compared to normal mice (Figs 2, 3). It was also associated with higher spontaneous production of $\mathrm{H}_{2} \mathrm{O}_{2}$ (Fig. 4) suggesting that the generation of reactive oxygen intermediates (ROIs) could be responsible for the higher fungicidal activity of those cells. Therefore the increased clearance of $C$. albicans from the peritoneal cavity after pretreatment with ATF can probably be attributed to a combination of these two factors. Our results are supported by the findings of Stevenhan and Furth (1993) who showed that the candidacidal activity of human granulocytes is associated with enhanced $\mathrm{H}_{2} \mathrm{O}_{2}$ production after stimulation with rIFN- $\gamma$.

Phagocytosis is essential for the destruction of some pathogens and during this process macrophages enhance the production of ROIs, including $\mathrm{H}_{2} \mathrm{O}_{2}, \mathrm{O}_{2}{ }^{-}$and $\mathrm{OH}^{-}$(Nathan \& Root 1977, Johnston et al. 1978), which are highly toxic to microorganisms (Sasada \& Johnston 1980). Our observations that ATF enhances the phagocytic and fungicidal activity of peritoneal macrophages are in agreement with this concept. In fact, the attachment of pathogens to macrophages can trigger the secretion of ROIs and NO, thus leading to their destruction (Goldsby et al. 2000). The linking of fungi to polymorphonuclear cells also induces the production of cytotoxic products such as $\mathrm{H}_{2} \mathrm{O}_{2}$ and $\mathrm{O}_{2}^{-}$, which exert fungicidal activity (Calderone et al. 1994).

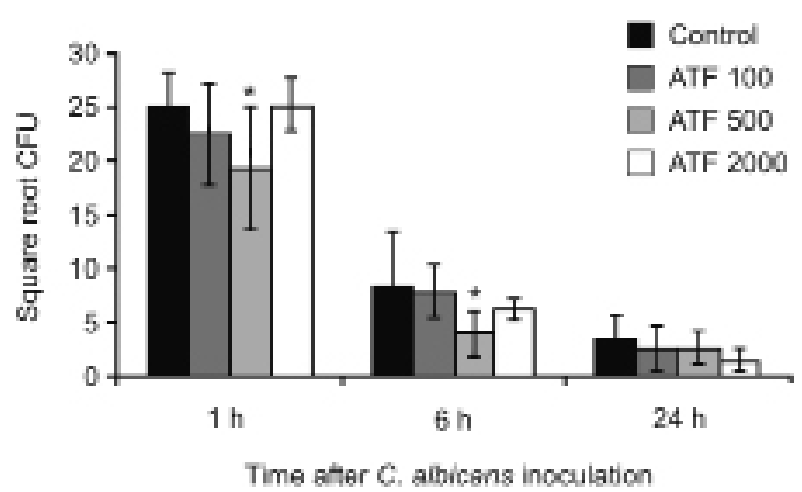

Fig. 7: effect of i.p. treatment with ATF on the in vivo clearance of C. albicans. Animals were treated with different doses of ATF and further infected i.p. with C. albicans. Clearence of yeast cells was checked by culturing peritoneal exsudate on Sabouraud culture medium plates. Results represent the mean \pm SD of eight mice in each group of a representative experiment (asterisks indicate $p<0,05$ compared to the respective controls; Student-Newman-Keuls Multiple Comparisons test applied on square roots of data).
Suzuki et al. (1990) demonstrated that oral administration of the $\beta-1,3$-glucan fraction, obtained from the Sclerotinia sclerotiorum culture supernatant, increases the candidacidal activity of murine peritoneal macrophages, in addition to $\mathrm{H}_{2} \mathrm{O}_{2}$ and IL-1 production. Sakurai et al. (1991) demonstrated that i.p. administration of this product also increases IL-1 production, which enhances the production of colony-stimulating factor, promoting the proliferation of alveolar macrophages and increasing their candidacidal activity. These data suggest that polysaccharides from this mushroom also could be useful against infectious diseases.

Administration of $(1 \rightarrow 3)-\beta$-D-glucan from Grifola frondosa also increases the production of $\mathrm{NO}$ by murine peritoneal macrophages and induces the expression of IFN- $\gamma$ mRNA in the liver and peritoneal cells, suggesting that the synthesis of NO is mediated by IFN- $\gamma$ (Ohno et al. 1996). In fact, Ding et al. (1988) stimulated peritoneal macrophages in vitro with 12 different cytokines and observed that only IFN- $\gamma$ was able to induce the production of NO. However, in the present study the increased candidacidal activity does not appear to involve NO production since we did not find any significant differences between the ATF-treated and control animals.

The enhancement of phagocytosis could be due to the higher expression of MR, a type of PRR associated with the phagocytosis of non-opsonized microorganisms like C.albicans (Asterie-Dequeker etal. 1998),Escherichia coli (Ofek et al. 1995) and even Mycobacterium tuberculosis (Shepherd \& Hoidal 1990). Actually, we observed that the increased MR expression induced by ATF was more intense than the effect of Con A, used as positive control, indicating the high activity of our product (Fig. 6). Mannosylated glycoproteins are recognized by these receptors, promoting endocytosis by macrophages and dendritic cells (Sallusto et al. 1995); and the attachment of microorganisms to MR causes intracellular signaling that is associated with several functional changes, including $\mathrm{O}_{2}$ - delivery (Berton \& Gordon 1983), and the synthesis of IL-1, IL-6, and GM-CSF (Yamamoto et al. 1997).

MR also appears to improve the integration of peptides to MHC molecules, thus enhancing the antigen presentation process (Sallusto et al. 1995, Yamamoto et al. 1997), indicating that this structure could have an important role in the development of specific immune response. However, MR is considered a marker of non-stimulated macrophages, since IFN- $\gamma$ induces it decreased expression on cell surface due to a lower level of mRNA transcription (Harris et al. 1992). Marodi et al. (1993) observed that the high $C$. albicans killing activity of IFN- $\gamma$-activated macrophages is associated with low MR expression, although the remaining MR showed increased phagocytic function.

In agreement with these reports, in the present study we observed that macrophages of ATF-treated animals showed increased MR but did not enhance the production of NO, suggesting that they were not activated in an IFN- $\gamma$-dependent way. Since ATF failed to induce NO production in our experimental conditions, it is possible to consider that the expression of MR and increasing 
of candidacidal activity were due to the stimulation of TH2 lymphocytes. This idea is supported by previous observation by our group that subcutaneous, inoculation of ATF was not able to induce the in vitro production of IFN- $\gamma$ and TNF- $\alpha$, but stimulated the production of IL-10 by spleen cells of normal mice (unpublished observations). In addition, Longoni et al. (1998) observed that IL-10 enhances MR expression by human monocyte-derived dendritic cells, and Stein et al. (1992) demonstrated that IL-4, a TH2 cytokine, increases both MR expression and MR-mediated endocytosis. In the present study we did not evaluate the effect of ATF on the production of IFN- $\gamma$ but, in a parallel investigation employing experimental infection with Paracoccidioides brasiliensis, we observed that the number of IFN- $\gamma$-producing cells (ELISpot) was diminished under treatment with ATF on the 14th day.

Although no toxicity had been observed, even by using the higher dose of $2,000 \mu \mathrm{g}$, our data showed that $500 \mu \mathrm{g}$ had a better effect on fungicidal activity of macrophages than $2,000 \mu \mathrm{g}$, both 1 and $6 \mathrm{~h}$ after C. albicans inoculation. We do not have an explanation for this, but $500 \mu \mathrm{g}$ appears to be the optimum concentration for treatment, since in the tumor model we also observed that this concentration had a better effect than higher ones (data not shown). Besides, we previously observed that $\beta$-glucan from Saccharomyces cerevisae also presented a better effect on fungicidal activity of macrophages against $P$. brasiliensis when animals were treated with a lower dose (20 $\mu \mathrm{g}$ vs. $100 \mu \mathrm{g})$ (Pelizon et al. 2005).

In summary, our data suggest that the polysaccharide-rich fraction of $A$. brasiliensis could enhance host resistance against infectious diseases by stimulating the microbicidal activity of macrophages. Considering that the increase of $\mathrm{H}_{2} \mathrm{O}_{2}$ was not followed by a similar increase in $\mathrm{NO}$ production, we suggest that $\mathrm{H}_{2} \mathrm{O}_{2}$ helped by MR-promoted phagocytosis may be sufficient to promote this phenomenon.

\section{ACKNOWLEDGEMENTS}

To Dr Julio Hoshimi Doyama, Dept de Química e Bioquímica, IBB/UNESP for help with ATF preparation, Dr Luis Cuadrado, Dept de Medicina Interna, FMB/UNESP for help with the dialysis system, and Dr Maria Fátima Sugizaki, Dept de Microbiologia e Imunologia, IBB/UNESP, for supply us with the sample of $C$. albicans.

\section{REFERENCES}

Ahn WS, Kim DJ, Chae GT, Lee JM, Bae SM, Sin JI, Kim YW 2004. Natural killer cell activity and quality of life were improved by consumption of a mushroom extract, cancer patients undergoing chemotherapy. Int J Gynecol Cancer 14: 589-594.

Asterie-Dequeker C, N'Diaye EN, Le Cebec V, Maridonneau-Parini I 1998. Mycobacteria are internalized into human macrophages through the mannose receptor and bypass the respiratory burst. Eur J Haematol 60: 330-331.

Berton G, Gordon S 1983. Modulation of macrophage mannosyl-specific receptors by cultivation on immobilized zymosan. Effects on superoxide-anion release and phagocytosis. Immunology 49: 705-715.

Borchers AT, Stern JS, Hackman RM, Keen CL, Gershwin ME 1999.
Mushrooms, tumors, and immunity. Proc Soc Exp Biol Med 221: 281-293.

Calderone R, Diamond R, Senet JM, Warmington J, Filler S, Edwards JE 1994. Host cell-fungal cell interations. J Med Vet Mycol 32: 151-164.

Ding AH, Nathan C, Stuehr DJ 1988. Release of reactive nitrogen intermediates and reactive oxygen intermediates from mouse peritoneal macrophages. Comparison of activating cytokines and evidence for independent production. J Immunol 141: 2407-2412.

Donders GG 2002. Lower genital tract infections in diabetic women. Curr Infect Dis Rep 4: 536-539.

Ebina T, Fujimiya Y 1998. Antitumor effect of a peptide-glucan preparation extracted from Agaricus blazei in a double-grafted tumor system in mice. Biotherapy 11: 259-265.

Fujimiya Y, Suzuki Y, Katakura R, Ebina T 1999. Tumor-specific cytocidal and immunopotentiating effects of relatively low molecular weight products derived from the basidiomycetes Agaricus blazei Murill. Anticancer Res 19: 113-118.

Fujimiya Y, Suzuki Y, Oshiman K, Kobori H, Moriguchi K, Nakashima H, Matumoto Y, Takahara S, Ebina T, Katakura R 1998. Selective tumoricidal effect of soluble proteoglycan extracted from the basidiomycete, Agaricus blazei Murill, mediated via natural killer cell activation and apoptosis. Cancer Immunol Immunother 46: 147-159.

Goldsby RA, Kindt TJ, Osborne BA 2000. Cells and organs of the immune system. In RA Goldsby, TJ Kindt, BA Osborne, Kuby Immunology, WH Freeman and Company, New York, p. 27-59.

Green LC 1981. Nitrite biossynthesis in man. Proc Natl Acad Sci 18: 7764-7768.

Grinde B, Hetland G, Johnson E 2006. Effects on gene expression and viral load of medicinal extract from Agaricus blazei in patients with chronic hepatitis $\mathrm{C}$ infection. Int Immunopharmacol 6: 1311-1314.

Harris N, Super M, Rits M, Chang G, Ezekowitz RAB 1992. Characterization of murine macrophage mannose receptor: demonstration that the downregulation of receptor expression mediated by interferon- $\gamma$ occurs at the level of transcription. Blood 80 : $2363-2373$.

Ito H, Shimura K, Itoh H, Kawade M 1997. Antitumor effects of a new polysaccharide-protein complex (ATOM) prepared from Agaricus blazei (Iwade strain 101) "Himematsutake"; and its mechanisms in tumor-bearing mice. Anticancer Res 17: 277-284.

Johnston Jr RB, Godzik CA, Cohn ZA 1978. Increased superoxide anion production by immunologically activated and chemically elicited macrophages. J Exp Med 148: 115-127.

Kawagishi H, Inagaki R, Kanao T, Mizuno T 1989. Fractionation and antitumor activity of the water-soluble residue of Agaricus blazei fruitig bodies. Carbohydr Res 186: 267-273.

Kawagishi H, Kanao T, Inagaki R, Mizuno T 1990. Formolysis of a potent antitumor $(1 \rightarrow 6)$ - $\beta$-D-glucan-protein complex from Agaricus blazei fruiting bodies and antitumor activity of the resulting products. Carbohydr Polym 12: 393-403.

Klein RS, Harris CA, Small CB, Moll B, Lesser M, Friedland GH 1984. Oral candidiasis in high-risk patients as the initial manifestation of the acquired immunodeficiency syndrome. New Eng J Med 311: 354-358.

Longoni D, Piemonti L, Bernasconi S, Mantovani A, Allavena P 1998. Interleukin-10 increases mannose receptor expression and endocytic activity in monocyte-derived dendritic cells. Int J Clin Lab Res 28: 162-169. 
Loyola W, Gaziri DA, Gaziri LC, Felipe I 2002. Concanavalin A enhances phagocytosis and killing of Candida albicans by mouse peritoneal neutrophils and macrophages. FEMS Immunol Med Microbiol 33: 201-208.

Marodi L, Schreiber S, Anderson CD, MacDermott RP, Korchak HM, Johnston Jr RB 1993. Enhancement of macrophage candidacidal activity by interferon-gamma: increased phagocytosis, killing and calcium signal mediated by a decreased number of mannose receptors. J Clin Invest 91: 2596-2601.

Mizuno T, Hagiwara T, Nakamura T, Ito H, Shimura K, Sumiya T, Asakura 1990a. Antitumor activity and some properties of water-soluble polysaccharides from Himematsutake, the fruiting body of Agaricus blazei Murill. Agric Biol Chem 54: 2889-2896.

Mizuno T, Inagaki R, Kanao T, Hagiwara T, Nakamura T, Ito H, Shimura K, Sumiya T, Asakura A 1990b. Antitumor activity and some properties of water-insoluble hetero-glycans from Himematsutake, the fruiting body of Agaricus blazei Murill. Agric Biol Chem 54: 2897-2905.

Muniz-Junqueira MI, Silva FO, de Paula-Júnior MR, Tosta CE 2005. Thalidomide influences the function of macrophages and increases the survival of Plasmodium berghei-infected CBA mice. Acta Trop 94: 128-138.

Nathan CF, Root RK 1977. Hydrogen peroxide release from mouse peritoneal macrophages dependence on sequential activation and triggering. J Exp Med 146: 1648-1662.

Nono I, Ohno N, Masuda A, Oikawa S, Yadomae T 1991. Oxidative degradation of an antitumor $(1 \rightarrow 3)-\beta$-D-glucan, Grifolan. J Pharmacobion-Dyn 14: 9-19.

Ofek I, Goldhar J, Keisari Y, Sharon N 1995. Nonopsonic phagocytosis of microorganisms. Annu Rev Microbiol 49: 239-276.

Ohno N, Egawa Y, Hashimoto T, Adachi Y, Yadomae T 1996. Effect of $\beta$-glucans on the nitric oxide synthesis by peritoneal macrophage in mice. Biol Pharm Bull 19: 608-612.

Pelizon AC, Kaneno R, Soares AMVC, Meira DA, Sartori A 2005. Immunomodulatory activities associated with $\beta$-glucan derived from Saccharomyces cerevisiae. Physiol Res 54: 557-564.

Pick A, Mizel A 1981. A rapid microassay of the measurements of superoxid and hydrogen peroxide production by macrophages in culture using automatic enzyme immunoassay reader. $J$ Iтmиnol 46: 2111-2126.

Ridola V, Chachaty E, Raimondo G, Corradini N, Brugieres L, Valteau-Couanet D, Hartmann O 2004. Candida infections in children treated with conventional chemotherapy for solid tumors (transplant recipients excluded) the Institut Gustave Roussy Pedriatrics Department Experience. Pediatr Blood Cancer 42: 332-337.

Sakurai T, Suzuki I, Kinoshita A, Oikawa S, Masuda A, Ohsawa M, Yadomae T 1991. Effect of intraperitoneally administered $\beta$-1,3glucan, SSG, obtained from Sclerotinia sclerotiorum IFO 9395 on the functions of murine alveolar macrophages. Chem Pharm Bull 39: 214-217.

Sallusto F, Cella M, Danieli C, Lanzavecchia A 1995. Dendritic cells use macropinocytosis and the mannose receptor to concentrate macromolecules in the major histocompatibility complex class II compartment: downregulation by cytokines and bacterial products. J Exp Med 182: 389-400
Sasada M, Johnston Jr RB 1980. Macrophage microbicidal activity. Correlation between phagocytosis-associated oxidative metabolism and the killing of candida by macrophages. J Exp Med 152: 85-98.

Schlesinger PH, Doebber TW, Mandell BF, White R, DeSchryver C, Rodman JS, Miller MJ, Stahl P 1978. Plasma clearance of glycoproteins with terminal mannose and $\mathrm{N}$-acetylglucosamine by liver non-parenchymal cells. Studies with beta-glucuronidase, $\mathrm{N}$-acetyl-beta-D-glucosaminidase, ribonuclease B and agalactoorosomucoid. Biochem J 176: 103-109.

Shepherd VL, Campbell EJ, Senior RM, Stahl PD 1982. Characterization of the mannose/fucose receptor on human mononuclear phagocytes. J Reticuloendothel Soc 32: 423-431.

Shepherd VL, Hoidal JR 1990. Clearance of neutrophil-derived myeloperoxidase by the macrophage mannose receptor. Am J Respir Cell Mol Biol 2: 335-340.

Smedsrod B, Einarsson M, Pertoft H 1988. Tissue plasminogen activator is endocytosed by mannose and galactose receptors of rat liver cells. Thromb Haemost 59: 480-484.

Sorimachi K, Akimoto K, Ikehara Y, Inafuku K, Okubo A, Yamazaki S 2001. Secretion of TNF-alpha, IL-8 and nitric oxide by macrophages activated with Agaricus blazei Murill fractions in vitro. Cell Struct Funct 26: 103-108.

Stahl P, Gordon S 1982. Expression of a mannosyl-fucosyl receptor for endocytosis on cultured primary macrophages and their hybrids. J Cell Biol 93: 49-56.

Stahl P, Rodman JS, Miller MJ, Schlesinger PH 1978. Evidence for receptor-mediated binding of glycoproteins, glycoconjugates, and lysosomal glycosidases by alveolar macrophages. Proc Natl Acad Sci 75: 1399-1403.

Stein M, Keshav S, Harris N, Gordon S 1992. Interleukin 4 potently enhances murine macrophage mannose receptor activity: a marker of alternative immunologic macrophage activation. J Exp Med 176: $287-292$

Stevenhagen A, Furth R 1993. Interferon-gamma activates the oxidative killing of Candida albicans by human granulocytes. Clin Exp Immunol 91: 170-175.

Suda M, Ohno N, Hashimoto T, Koizumi K, Adachi Y, Yadomae T 1996. Kupffer cells play important roles in the metabolic degradation of a soluble anti-tumor $(1 \rightarrow 3)$-beta-D-glucan, SSG, in mice. Fems Immunol Med Microbiol 15: 93-100.

Suzuki I, Tanaka H, Kinoshita A, Oikawa S, Osawa M, Yadomae T 1990. Effect of orally administered $\beta$-glucan on macrophage function in mice. Int J Immunopharmacol 12: 675-684.

Wasser SP, Diduck MY, Amazonas MLLA, Nevo E, Stamets P, Eira AF 2002. Is a widely cultivated culinary-medicinal royal sun Agaricus (the himematsutake mushroom) indeed Agaricus blazei Murrill? Intern J Medicinal Mush 4: 267-290.

Yamamoto Y, Klein TW, Friedman H 1997. Involvement of mannose receptor in cytokine interleukin-lbeta (IL-lbeta), IL-6, and granulocyte-macrophage colony-stimulating factor responses, but not in chemokine macrophage inflammatory protein lbeta (MIP-1beta), MIP-2, and KC responses, caused by attachment of Candida albicans to macrophages. Infect Immun 65: 1077-1082. 